DOI: $10.21802 / \mathrm{artm} .2020 .2 .14 .137$.

УДК $616-002.525: 615.825$

\title{
МЕТОДИ ОЦІНКИ ЯКОСТІ ЖИТТЯ ХВОРИХ НА СИСТЕМНИЙ ВОВЧАК
}

\author{
М.А. Мазепа, І.В. Гавалко
}

Львівський державний університет фізичної культури імені Івана Боберського, кафедра фізичної терапї та ерготерапії, ORCID ID: 0000-0002-2199-4791, ORCID ID: 0000-0003-4854-8043, e-mail:mrmazepa@ukr.net

Резюме. У публікації представлені сучасні підходи до оцінки якості життя (ЯЖ) хворих на системний червоний вовчак (СЧВ) і критичний аналіз методів оцінки активності захворювання, загальних та специфічних опитувальників, які найбільш об'єктивно відображають стан хворого. Представлена публікація є наративним оглядом. Пошук даних проводили в базі статей у галузі медицини і біології сайту PubМеd Національного центру біотехнологічної інформації США (NCBI) та пошуковій системі Google Scholar. Аналіз літератури показав, що СЧВ істотно погіршує ЯЖ пацієнтів. У хворих на СЧВ визначена основна ключова тріада проблем, що викликає погіршення ЯЖ - втома, біль і депресія. Корисність загальних опитувальників щодо ЯЖ у пацієнтів із СЧВ визначена не до кінця, однак більшість авторів в якості «золотого стандарту» рекомендують використовувати загальний опитувальник - SF-36 (валідизований в Україні). Із 60-ти індексів активності СЧВ тільки п'ять пройшли валідизацію й широко використовуються у світовій медичній лікувальній і науковій практиці. Наведені спеціальні для СЧВ опитувальники ЯЖ є достатньо чутливим до даної нозології, вони займають небагато часу для відповідей. Їх використання залежить від запиту пацієнта і цілей, які він ставить перед собою (Т2Т). Опитувальник буде ефективним, якщо його раціонально застосувати в кожному конкретному випадку. Знання змін результатів, повідомлених пацієнтом, проти клінічно значущих змін у перебігу СЧВ, має вирішальне значення для управління хворобою, спрямованого на персоналізовану медицину. Важливо, щоб опитувальник був валідизований і пристосований до умов певної країни. Спеціальні опитувальники ЯЖ хворих на СЧВ потрібно валідизувати в Україні.

Ключові слова: системний червоний вовчак, активність, якість життя, питальники.

Вступ. Системний червоний вовчак (СЧВ) одне 3 найбільш важких автоімунних захворювань людини, що вражає практично всі органи і системи. Сучасна концепція Treat to Target при СЧВ (Т2Т) спрямована на досягнення довгострокової виживаності, попередження незворотних уражень органів, поліпшення якості життя, пов'язаної зі здоров'ям, за рахунок контролю активності СЧВ, мінімізації проявів коморбідних захворювань та токсичності ліків [3].

Це стало можливим завдяки вдосконаленню діагностичних критеріїв СЧВ, розробці індексів активності, появі генно-інженерних біологічних препаратів. У 1985 р. на конференції в Торонто, присвяченій прогнозу у хворих на СЧВ, було зазначено, що, крім активності захворювання i ступеня пошкодження органів, необхідно оцінювати у таких пацієнтів якість життя (ЯЖ). Однак тільки у 2014 році оцінка якості життя стала одним 3 основоположних принципів Т2Т при СЧВ [23].

Якість життя хворих на СЧВ залишається нижчою від популяційного рівня, а в порівнянні 3 іншими ревматичними захворюваннями ЯЖ хворих на СЧВ є однією з найнижчих. Оцінка впливу СЧВ на ЯЖ пацієнтів є актуальною і включає в себе: оцінку активності захворювання, пошкодження органів i систем [2].

Активність захворювання та рівень ураження органів оцінює лікар. Фізичний терапевт оцінює функцію уражених органів і систем та якість життя пацієнта. Якість життя пацієнта дає змогу і лікарю, і фізичному терапевту персоніфікувати лікувальний процес. Завдяки оцінці якості життя є можливість оцінити пацієнта цілісно, з урахуванням не тільки клінічного стану, а й емоційного та психічного благополуччя, а також соціально-економічних чинників. Це важливо також з позицій турботи про вибір терапевтичного лікування. Здійснення агресивного лікування зменшує активність захворювання або рівень ураження органів, проте побічні ефекти впливають на самопочуття пацієнта і функціонування в сімейному житті та на роботі, у результаті чого виникає ризик недотримання рекомендацій лікаря. Оцінка ЯЖ хворого на СЧВ полегшує планування організації догляду за пацієнтами та забезпечення належних стосунків між лікарем, фізичним терапевтом, ерготерапевтом i пацієнтом.

Встановлені ключові параметри, що істотно погіршують ЯЖ у хворих на СЧВ: невизначеність або непередбачуваність перебігу й віддаленого прогнозу захворювання, емоційні труднощі, пов'язані 3 перспективою кар'єри або можливої втрати доходу, зміна зовнішності та наслідки гормональної, цитостатичної та біологічної терапії, порушення пам'яті й концентрації уваги, залежність від інших людей і страх планування сім'ї [10]. 
Мета дослідження: представити сучасні підходи до оцінки якості життя хворих на СЧВ і дати критичний аналіз методів оцінки активності захворювання, загальних та специфічних опитувальників, які найбільш об'єктивно відображають стан хворого.

Матеріали i методи. Представлена публікація $\epsilon$ наративним оглядом. Пошук даних проводили в базі статей у галузі медицини і біології сайту PubMed Національного центру біотехнологічної інформації США (NCBI) та пошуковій системі Google Scholar. До огляду були включені повнотекстові статті, у яких наведені та проаналізовані методи оцінки ЯЖ у хворих на СЧВ. Пошук у базі PubMed проводили за такими ключовими словами: «systemic lupus erythematosus», «health-related quality of life», «quality of life», «disease activity index for lupus », «Physical activity», «Rehabilitation», «Physiotherapy», «Physical therapy».

Результати дослідження та їх обговорення. Оцінка активності СЧВ. Особливий інтерес викликає зв'язок між ЯЖ та активністю СЧВ. Оцінка активності захворювання здійснюється за допомогою різних індексів, кількість яких сягає близько 60-ти, однак тільки п'ять індексів активності СЧВ пройшли валідизацію та широко використовуються у світовій медичній лікувальній і науковій практиці: SLE Disease Activity Index (SLEDAI)( Індекс активності СЧВ); Systemic Lupus Activity Measure (SLAM) (Ступінь активності вовчака); European Consensus Lupus Activity Measurement (ECLAM) (Свропейський консенсус вимірювання активності СЧВ); Lupus Activity Index (LAI) (Індекс активності вовчака); Classic British Isles Lupus Assessment Group Index (Classic BILAG Index) (Класичний індекс групи оцінювання вовчака на Британських островах) $[1 ; 2]$.

Найпоширенішим 3 них $\epsilon$ індекс активності захворювання SLEDAI, за допомогою якого оцінюють загальну активність. Цей індекс оцінки загальної активності захворювання був розроблений у 1985 р. в Торонто на основі заповнення анкет, що включають 37 клінічних ознак СЧВ. Максимально можливе значення SLEDAI становить 105 балів. За індексом SLEDAI виділяють наступні ступені активності СЧВ: немає активності (SLEDAI 0 балів), низька активність (SLEDAI 1-5 балів), середній ступінь активності (SLEDAI 6-10 балів), висока ступінь активності (SLEDAI 11-19 балів) і дуже висока ступінь активності (SLEDAI > 20 балів). Збільшення SLEDAI між двома візитами на 3-12 балів трактується як помірне загострення, більш ніж на 12 балів - як важке загострення СЧВ. У даний час широко використовуються три модифікації індексу SLEDAI: SLEDAI 2000, SELENA-SLEDAI, MexSLEDAI.

SLEDAI 2000 (SLEDAI 2K). У цей індекс внесені: протеїнурія>0,5 г/доб., шкірні висипання, алопеція, виразки слизових оболонок. Дозволяє враховувати персистуючу активність, у той час як SLEDAI враховує тільки виникнення або рецидив цих ознак.

SELENA-SLEDAI. Модифікований у 2005 році. Передбачає: ураження черепних нервів, наявність плевриту або перикардиту, підвищення протеїнурії на 0,5 г/доб. враховує лише при пї виникненні протягом 10 днів.

Mex-SLEDAI. Розроблений у 1992 році в першу чергу для використання в країнах, що розвиваються, через труднощі визначення рівня антитіл до ДНК і компонентів комплементу. Він включає 13 ознак замість 24: ураження нервової системи, нирок, шкіри і слизових оболонок, васкуліт, гемоліз, тромбоцитопенія, міозит, артрит, серозит, гарячка, втома, лейкопенія і лімфопенія. Значення Mex-SLEDAI може коливатись від 0 до 32 балів. Показник $<2$ балів показує неактивне захворювання, від 2 до 5 - можливу активність, > 5 балів - явну активність захворювання. Цей індекс і в даний час активно використовується в латиноамериканських країнах для визначення активності СЧВ.

Провівши опитування 580 хворих на СЧВ Kernder i співавт. проілюстрували зв'язок між якістю допомоги хворим на СЧВ, активністю захворювання, шкодою, пов'язаною із захворюванням та ЯЖ, і вважають, що врахування цих параметрів може бути хорошим підходом для покращення результатів лікування пацієнтів із СЧВ [9; 19].

Ступінь ураження органів оцінюється із застосуванням індексів SLICC та ACR (Індекс пошкодження Systemic Lupus International Collaborating Clinics and American Collage of Rheumatology, Мінародна співпраця клінік системного вовчака i американського коледжу ревматологіi) [13].

Проблеми функціонування Ta життсдіяльності у хворих на СЧВ, що впливають на ЯЖ. У функціонуванні та життєдіяльності у хворих на СЧВ визначені наступні проблеми: втома $\mathrm{i}$ біль; порушення сприйняття образу тіла (оцінка пацієнтом свого тіла); знижена можливість справлятися 3 ситуацією, стресом, емоціями; порушення в сексуальній сфері; неможливість планування; проблеми з кар'єрою [5].

Втома $i$ біль. Втома зустрічається практично у $80 \%$ випадків у хворих на СЧВ. Вона завжди супроводжується фізичними і психологічними порушеннями, що включають біль у суглобах, тривогу, депресію, погану якість сну. Ступінь активності захворювання, як правило, не корелює 3 втомою. Більшою мірою втому при СЧВ пов'язують 3 депресією, порушеннями сну i фіброміалгією. Багатофакторний статистичний аналіз показав, що першочергове значення в формуванні симптомів втоми при СЧВ відіграє депресія [6]. Соціальноекономічні зміни, такі як відсутність особистого страхування, низький рівень доходів, соціальної підтримки були пов'язані 3 більшою виразністю втоми. Пацієнти з СЧВ відзначають досить високий ступінь болю, що посилюється при значному фізичному навантаженні (підйомі по сходах, тривалому перебуванні в положенні стоячи і тривалій прогулянці пішки). Біль у суглобах і грудній клітці у хворих СЧВ вимагає прийому більшої кількості медикаментів.

Порушення сприйняття образу тіла (оиінка пацієнтом свого тіла). У пацієнтів 3 СЧВ $є$ різноманітні шкірні прояви, крім того, тривала 
терапія глюкокортикостероїдами призводить до виникнення ожиріння i синдрому Іценко-Кушинга, розвиваються порушення, пов'язані зі сприйняттям власного тіла, іноді це передує розвитку депресії [7; 17].

Неможливість справлятися з ситуацією, стресом, емоиіями. У пацієнтів із СЧВ виникає порушення психологічного функціонування, яке викликається депресією внаслідок того, що пацієнт через хворобу не може більше виконувати свою соціальну роль або якщо хвороба позбавляє його соціальної значущості, до якої він звик $[10 ; 18]$.

Порушення в сексуальній сфері. Дослідження, опубліковані протягом останнього десятиліття, показують, що жінки з СЧВ мають занижену сексуальну функцію i, як правило, утримуються від сексуальної активності частіше (26\%), ніж здорові жінки (4\%). У пацієнток 3 СЧВ більш часто виявляються гінекологічні проблеми, знижується сексуальне функціонування, більш виражена депресія і порушення, пов'язані зі сприйняттям свого тіла [14; $18]$.

Неможливість планування та проблеми з кар'єрою. Пацієнти повідомляли, що вони не в змозі планувати заздалегідь свою присутність на заходах у зв'язку з непередбачуваністю перебігу СЧВ. Деякі хворі були стурбовані тим, що цим вони ізолюють себе у майбутньому від звичного спілкування. Багато пацієнтів змушені залишати роботу i/або переходити на більш легку, тим самим втрачаючи звичний дохід і посилюючи емоційні порушення [20]. Молоді пацієнти стурбовані тим, що хвороба перешкоджає професійному росту, однак багато пацієнтів, залишаючи роботу, переживали почуття полегшення у зв'язку з тим, що вони більше не є тягарем для колег [13].

Використавши поперечний дизайн дослідження у 104 жінок із СЧВ автори показали, що активність захворювання, ступінь втоми, психологічна захворюваність та образ тіла були пов'язані 3 усіма областями ЯЖ. При цьому психологічна захворюваність та активність захворювання суттєво впливали на сприйняття пацієнтками образу тіла [17].

Характеристика питальників, що використовуються для оцінки ЯЖ у хворих на СЧВ. Оскільки одним з основних принципів фізичної терапії $\epsilon$ пацієнтоцентричність, слід враховувати запит пацієнта i створити адекватну програму фізичної терапії. Провівши опитування якості життя хворих на СЧВ, ми зможемо отримати об'єктивну оцінку його ЯЖ, що допоможе в процесі терапії. Основним інструментом для «кількісного» визначення якості життя є опитувальники, що містять цілу низку запитань, відповідаючи на які людина максимально повно подає інформацію про різні сторони свого життя чи стан здоров'я. Це робить оцінку якості життя досить точною.

Загалом усі наявні на сьогодні опитувальники можна розподілити за специфічністю, об'ємом, побудовою та способом аналізу результатів, за респондентом, способом отримання інформації. За специфічністю опитувальники поділяють на загальні та специфічні. Загальні опитувальники застосовують для оцінки якості життя як у здорових людей, так і в людей 3 різними захворюваннями. Загальні опитувальники недостатньо чутливі при застосуванні до конкретної нозологічної одиниці. Крім того, результати дослідження можуть змінюватись під впливом факторів, не пов'язаних із хворобою, що досліджується. Саме тому для вивчення якості життя при конкретних нозологічних одиницях використовують специфічні опитувальники.

У даній статті зупинимось на загальних та специфічних опитувальниках, що використовуються у хворих на СЧВ у клінічній практиці та наукових дослідженнях.

До загальних опитувальників, які найчастіше застосовуються для оцінки якості життя, належать: 1. Medical Outcomes Study 36-Item Short-Form Health Status (SF-36); 2. Medical Outcomes Survey-Short Form 20 (SF-20); 3. EuroQoL-5D, Quality of Life Index; 4. QOLS (Quality of life scale); 5. World Health Organization Quality of Life- Bref (WHOQol-Bref); 6. MHAQ (Modified Health Assessment Questionnaire); 7. Sickness Impact Profile (SIP); 8. The Sickness Impact Profile, McMaster Health Index Questionnaire; 9. Nottingham Health Profile, General Health Rating Index; 10. Госпітальна шкала тривоги і депресії (HADS); 11. Шкала оцінки ступеню втоми (Fatigue Assessment Scale (FAS).

Недоліком загальних опитувальників вважається неможливість оцінити вплив симптомів окремих захворювань на показники ЯЖ, тобто недостатня чутливість при конкретній нозології.

Серед загальних опитувальників як у здорових людей, так і при захворюваннях найчастіше використовують коротку форму SF-36, яка пройшла валідизацію в Україні [4], а група SLICC (Systemic Lupus International Collaborating Clinics Group) y 1997 р. для вивчення ЯЖ у хворих на СЧВ в якості «золотого стандарту» рекомендувала використовувати загальний опитувальник - SF-36 [15]. Усі 36 пунктів опитувальника згруповані у вісім шкал: фізичне функціонування, рольова участь, біль, загальне здоров'я, життєздатність, соціальне функціонування, емоційний стан і психічне здоров'я. Показники кожної шкали варіюють між 1 і 100, де 100 - пацієнт повністю здоровий. Всі шкали формують два показники: психічне i фізичне благополуччя. Результати представляються у вигляді оцінок у балах за 8 шкалами, які складені таким чином, що більш висока оцінка вказує на більш високий рівень ЯЖ. Коротка форма SF-36 у 2004 р. рекомендована J.Schiffenbauer i співавт. до використання в клінічних дослідженнях для оцінки ЯЖ у хворих СЧВ [20].

$\boldsymbol{S F - 2 0}$ - це скорочена версія опитування SF36, містить 20 питань, розділених на 6 доменів. Опитування триває 5 хв. Оцінює фізичне, рольове, соціальне функціонування, психічне здоров'я, сприйняття здоров'я та біль. Більш висока оцінка вказує на кращий рівень якості життя. 
Анкета EQ-5D включає 5 питань щодо мобільності, догляду за собою, звичних занять, болю та депресії, часто використовується для оцінки загального стану здоров'я, характеризується хорошою достовірністю та надійністю, опитування триває 2-5 хв. Оцінює рухливість, догляд за собою, звичайні заняття, біль і депресію. Більш висока оцінка вказує на кращий рівень ЯЖ.

WHOQOL у повній його версії (WHQORL100) містить 100 питань, тоді як скорочена версія (BREF), яка частіше використовується, включає 26 питань. WHOQOL-BREF вимірює такі сфери якості життя: фізичне здоров'я, психологічне здоров'я, соціальні відносини та навколишнє середовище.

Візуальна аналогова шкала (VAS) візуальний інструмент, що використовує аналогову шкалу 100 мм, на якій пацієнт (і лікар) позначає вертикальною лінією положення, що відповідає інтенсивності оцінюваного явища. Результат вимірюється від початкової точки шкали до зазначеної позиції.

Госпімальна икала тривоги $і$ депресії (HADS). Госпітальна шкала тривоги і депресії (Hospital Anxiety and Depression Scale) розроблена для виявлення та оцінки рівня тривоги і депресії в умовах загальномедичної практики. Шкала складається із 14 запитань. Непарні питання $(1,3,5,7,9,11)$ складають підшкалу тривоги, а парні $(2,4,6,8,10,12,14)$ підшкалу депресії. На кожне питання $є$ чотири варіанти відповіді, які відображають вираженість ознак і кодуються відповідно до наростання важкості симптомів від 0 (відсутні) до 3 (максимально виражені). Суму балів підраховується окремо для підшкали тривоги і для підшкали депресії. Виділяють такі межі суми балів для кожної шкали: 0-7 балів - норма; 8-10 балів - субклінічно виражена тривога чи депресія; 11 балів і більше - клінічно виражена тривога чи депресія. Шкала має високу дисклимінантну валідність щодо двох розділів: тривоги і депресії.

Переваги даної методики полягають у простоті застосування та обробки даних, що дає змогу використовувати іiі в загальносоматичній практиці для первинного виявлення тривоги та депресії у пацієнтів.

Шкала оцінки ступеню втоми (Fatigue Assessment Scale (FAS)). Складається із 10 запитань. П'ять питань відображають фізичну втому та 5 питань (питання 3 і 6-9) психічну втому. Відповідь на кожне питання повинна бути подана, навіть якщо на цей момент у людини немає жодних скарг. Оцінки на запитання 4 і 10 слід перекодувати $(1=5,2=4,3=3$, $4=2,5=1)$. Загальна оцінка FAS може бути розрахована шляхом підсумовування балів за всіма питаннями (перекодований бал для запитань 4 та 10). Загальна оцінка становить від 10 до 50. Загальний показник FAS $<22$ показує відсутність втоми, оцінка $\geq 22$ означає наявність втоми. Виражена стомлюваність: показник FAS $\geq 35$.

Спеціальні опитувальники. У даний час для оцінки ЯЖ у пацієнтів з СЧВ застосовується вісім валідизованих опитувальників: SLE Symptom checklist (SSC) (Перелік симптомів СЧВ); SLEspecific Quality of Life questionnaire (SLE-QoL)
(Специфічний опитувальник якості життя при СЧВ); SLE Quality of Life Questionnaire (L-QoL) (Опитувальник якості життя при СЧВ); Lupus Quality of Life (LUP-QoL) (Опитувальник якості життя при СЧВ); Patient-Reported Outcomes in Systemic Lupus Erythematosus (LupusPRO) (Підсумки пацієнтів 3 СЧВ); Lupus Quality of Life (LupusQoL) (Опитувальник якості життя при СЧВ); Simple Measure of Impact of Lupus Erythematosus in Youngsters (SMILEY) (Прості засоби впливу СЧВ у молоді).

SLE Symptom checklist - цей опитувальник не $є$ справжнім інструментом для вимірювання ЯЖПЗ у хворих на СЧВ, так як містить лише перелік симптомів захворювання. Опитувальник SLE Symptom checklist включає в себе 38 симптомів СЧВ, пов'язаних 3 ЯЖ і лікуванням СЧВ. Симптоми оцінюються пацієнтами і лікарями за чотирибальною шкалою, де «0» $є$ найкращим станом здоров'я, а «4»найгіршим. Валідизований у 2003 р. в Нідерландах, у 2007 році проведена його культурна і мовна адаптація в Бразилії.

SLE-QoL - достатньо чутливий і дозволяє оцінити клінічно мінімально значущі відмінності. Містить 40 питань, що об'єднані у 6 шкал: Physical Functioning (фізичного функціонування), activities (діяльності). SLE Symptoms (симптом СЧВ), treatment (лікування), mood (настрій), self-image (сприйняття власного образу). Опитування триває менш ніж 5 хв. Кількість балів від 40 до 280. Більш висока кількість балів вказує на гірший показник ЯЖ. При оцінці в дослідженні, у якому проводили його порівняння 3 опитувальником SF-36, була виявлена низька кореляція по замінності шкал, у зв'язку 3 цим розробники опитувальника рекомендують використовувати його в якості додаткового інструменту для оцінки ЯЖПЗ. Оцінюється за 7бальною шкалою, при цьому підрозділи мають різні значення, у тому числі від «не складно» до «надзвичайно складно», від «не зовсім» до «надзвичайно складно», і від «зовсім не» до «дуже часто». Загальний рахунок становить від 40 до 280 балів, більш високий свідчить про гіршу ЯЖ. Опитувальник заповнюється в письмовому вигляді протягом 5 хв. Валідизовано англійською мовою в 2005 р. у Сінгапурі. У 2007 р він пройшов культурну і мовну адаптацію в Китаї, у 2010 р. - в Бразилії.

$\boldsymbol{L - Q o L}$ - опитування триває менше 5 хв. Містить 25 питань, що об'єднані у 3 шкали: 1. SelfCare (самообслуговування). 2. Fatigue (втома). 3. Emotional Reactions (емоційні реакції). Опитувальник заснований на постулаті про те, що ЯЖ залежить від можливості й здатності людей задовольняти свої потреби. Питання дозволяють оцінювати загальний вплив СЧВ і пов'язаного 3 нею лікування на ЯЖ пацієнта. Складається з 25 питань, розподілених у три шкали: рахунок від 0 до 25 балів, більш високий бал означає гіршу ЯЖ. Заповнюється протягом 5 хв. Валідизований у 2008 році у Великобританії. Кількість балів від 0 до 25. Більш висока кількість балів вказує на гірший показник ЯЖ. При первинній валідизації опитувальника продемонстровані його надійність і достовірність, однак потрібне додаткове тестування, щоб підтвердити дані результати. Крім 
того, не проводилися визначення чутливості і тестування опитувальника у хворих 3 високою активністю СЧВ, що необхідно при використанні його для оцінки проведеної терапії в міжнародних клінічних дослідженнях.

LUP-QoL - створений у 2006 році для пацієнтів 3 легкою i середньою активністю захворювання. Показав хорошу надійність і відтворюваність, проте в даний час у клінічних дослідженнях ЯЖПЗ не застосовується, оскільки не проведена його остаточна валідизація.

LupusPRO - був розроблений на основі відгуків та остаточної оцінки пацієнтами із СЧВ у американського населення різного етнічного походження та будь-якої статі. Містить 43 питання, що об'єднані у 12 шкал: 1. Симптоми СЧВ. 2. Терапія СЧВ. 3. Пізнавальні здібності. 4. Репродуктивна функція. 5. Фізичне здоров'я. 6. Емоційне здоров'я. 7. Життездатність. 8. Образ тіла. 9. Якість життя, не пов'язана зі здоров'ям. 10. Бажання і цілі. 11. Можливість впоратися 3 ситуацією. 12. Соціальна підтримка. Як видно, цей опитувальник оцінює якість життя, пов'язану і не пов'язану зі здоров'ям. Однак не встановлено, чи охоплює опитувальник все коло проблем пацієнтів з СЧВ. За даними M. Jolly i співавт. існує хороший взаємозв'язок опитувальника 3 індексом активності BILAG, при цьому не зазначено взаємовпливу 3 індексом SELENA-SLEDAI та ВП SLICC / ACR. Оцінюється в балах від 0 до 100; чим вище бал, тим кращий показник ЯЖ. Оцінка займає більше 10 хв. Анкета враховує зміни, що виникають у часі. Він вважається дійсним і надійним інструмент для оцінки пацієнтів із СЧВ [8].

LupusQoL розроблений у Великобританії. Дана анкета складається з 34 питань. Питання в свою чергу поділяються на 8 доменів (блоків): "Фізичне здоров'я" складається 38 питань, "Біль" - 33 питань, "Планування" - 33 питань, "Інтимні стосунки" - 32 питань, "Тягар, що накладається на інших " - 33 питань (сприйняття пацієнтом тягаря, який він надає близьким йому людям), "Емоційне здоров'я" - 36 питань, "Образ тіла" - 35 питань (сприйняття пацієнтом впливу, що чиниться СЧВ на його зовнішність і привабливість), "Втома" - 34 питань. Відповіді відповідають п'ятибальною шкалою Лайкерта: 0 - постійно, 1 - майже завжди, 2 - досить часто, 3 - зрідка, 4 - ніколи. Оцінка ЯЖ набуває значення від 0 до 100 , де 100 оптимальне значення, а 0 - найгірше. LupusQoL перекладений на 77 мов для використання в 51 країні [22].

SMILEY - призначений для оцінки ЯЖПЗ у дітей 3 СЧВ. Якщо дитина віком до 7 років, опитувальник заповнюють батьки [12].

Висновки. Аналіз літератури показав, що СЧВ істотно погіршує ЯЖ пацієнтів. У хворих на СЧВ на підставі багатьох досліджень визначена основна ключова тріада проблем (втома, біль і депресія), що викликає погіршення ЯЖ.

Недоліком загальних опитувальників вважається недостатня чутливість при конкретній нозології. Корисність загальних опитувальників щодо ЯЖ у пацієнтів із СЧВ визначена не до кінця, однак більшість авторів для вивчення ЯЖ у хворих на СЧВ в якості «золотого стандарту» рекомендують використовувати загальний опитувальник - SF-36 (валідизований в Україні).

Існує зв'язок між ЯЖ та активністю СЧВ, хоча він також визначений не до кінця. Із 60-ти індексів активності СЧВ тільки п'ять пройшло валідизацію і широко використовуються у світовій медичній лікувальній і науковій практиці.

Спільним для специфічних опитувальників ЯЖ при СЧВ є те, що всі наведені опитувальники є достатньо чутливим до даної нозології, вони займають 5-10 хв. часу для відповідей i кожний пацієнт може без сторонньої допомоги дати відповідь. Їх використання залежить від запиту пацієнта і цілей, які він ставить перед собою (Т2Т). У цих випадках доцільним буде використання LupusPRO. У $\boldsymbol{S L E - Q o L}$ більше звертаєтья увага на фізичне функціонування, лікування, настрій, сприйняття власного образу, у $\boldsymbol{L}$ $\boldsymbol{Q o L}$ - на самообслуговування, втому, емоційні реакції, у Lupus $\boldsymbol{Q o L}$ - фізичне здоров'я, біль, інтимні стосунки, емоційне здоров'я, образ тіла, втому. Деякі опитувальники застосовують при низькому i середньому індексі активності - LUP-QoL, інші - при високому. А в такому опитувальнику як LupusPRO не зазначено взаємовпливу з індексом SELENA-SLEDAI та ВП SLICC / ACR. Тобто опитувальник буде ефективним, якщо правильно його застосувати.

Знання змін результатів, повідомлених пацієнтом, проти клінічно значущих змін у перебігу СЧВ, має вирішальне значення для управління хворобою, спрямованого на персоналізовану медицину. Важливу роль в оцінці ЯЖ хворих на СЧВ відіграє дизайн дослідження.

Важливо, щоб опитувальник був валідизований i пристосований до умов певної країни. Спеціальні опитувальники ЯЖ хворих на СЧВ потрібно валідизувати в Україні.

\section{References:}

1. Abysheva S, Sarmanova A. Voprosu kachestva zhyzny v kompleksnom obsledovanyy patsyentov s systemnoi krasnoi volchankoi. Nauchnopraktycheskaia revmatolohyia; 2014; 52(4):445-450. Dostupno na: http://dx.doi.org/10.14412/1995-44842014-445-450.

2. Vorobeva LD, Aseeva E. Znachenye kachestva zhyzny, sviazannohoso zdorovem, u bolnykh systemnoi krasnoi volchankoi y sovremennye instrymentu eho otsenky. Sovremennaia revmatolohyia; 2017; 11(4):62-72.

3. Solovev S, Aseeva E, Popkova T y dr. Stratehyia lechenyia systemnoi krasnoi volchanky «Do dostyzhenyia tsely» (Treat-to-Target SLE). Pekomendatsyy mezhdunarodnoi rabochei hruppы y kommentaryy rossyiskykh эkspertov. Nauchnopraktycheskaia revmatolohyia; 2015; 53(1):9-16.

4. Feshchenko Y. Protsedura adaptatsii mizhnarodnoho opytuvalnyka otsinky yakosti zhyttia MOS SF-36 v Ukraini. Dosvid zastosuvannia u khvorykh bronkhialnoiu astmoiu. Ukrainskyi pulmonolohichnyi zhurnal; 2002; 3:9-11. 
5. Cleanthous $\mathrm{S}$, Tyagi $\mathrm{M}$, Isenberg $\mathrm{D}$, Newman $\mathrm{S}$ What do we know about self-reported fatigue in systemic lupus erythematosus? Lupus 2012; 21:465-76.

6. Holloway L, Humphrey L, Heron L, et al. Patientreported outcome measures for systemic lupus erythematosus clinical trials: a review of content validity, face validity and psychometric performance. Health Qual Life Outcomes. 2014; Jul, 22; 12:116. doi: 10.1186/ s12955-014-0116-1.

7. Ji L, Lili S, Jing W, et al. Appearance concern and depression in adolescent girls with systemic lupus erythematous. Clin Rheumatol. 2012; 31:1671-5. doi: 10.1007/s10067-012-2071-8.

8. Jolly M, Pickard AS. Disease-specific patient reported outcome tools for systemic lupus erythematosus. Semin Arthritis Rheum 2012; 42:56-65.

9. Kernder A, Richter JG, Fischer-Betz R, WinklerRohlfing B, Brinks R, Schneider M and Chehab G Quality of care predicts outcome in systemic lupus erythematosus: a cross-sectional analysis of a German long-term study (LuLa cohort) Lupus. 2020; 29:136143.

10. Lau C, Mak A. The socioeconomic burden of SLE. Nat Rev Rheumatol. 2009; 5:400-4. doi: 10.1038/nrrheum.2009.106.

11. Liang M, Socher S, Larson M et al. Reliability and validity of six systems for the clinical assessment of disease activity in systemic lupus erythematosus. Arthr Rheum. 1989; 32:1107-18.

12. Louthrenoo W, Kasitanon N, Morand E, KandaneRathnayake R. Comparison of performance of specific (SLEQOL) and generic (SF36) health-related quality of life questionnaires and their associations with disease status of systemic lupus erythematosus: a longitudinal study. Arthritis Res Ther. 2020; Jan, 10; 22(1):8. doi: 10.1186/s13075-020-2095-4.

13. Marzena O, Agata S. Quality of life in systemic lupus erythematosus and its measurement. Reumatologia 2018; 56(1):45-54. DOI: https://doi.org/ 10.5114/ reum.2018.74750.

14. Mcelhone K, Abbott J, Shelmardine J. et al. Development and validation of a disease-specific health-related quality of life meas- ure, the lupusQoL, for adults with systemic lupus erythematosus. Arthr Rheum 2007; 57:972-9.

15. McElhone K. et al. Development and validation of a disease McElhone K, Abbott J, Gray J, Williams A, Teh L. Patient perspective of systemic lupus erythematosus in relation to healthrelated quality of life concepts: a qualitative study. Lupus. 2010; 19:1640-7. doi: 10.1177/0961203310378668.

16. Petri M, Hellmann D, Hochberg M. Validity and reliability of lupus activity measures in the routine clinic setting. J Rheumatol. 1992; 19:53-9.

17. Pereira MG, Duarte S, Ferraz A, Santos M, Fontes L. Quality of life in patients with systemic lupus erythematosus: the mediator role of psychological morbidity and disease activity. Psychol Health Med. 2020; Feb, 24:1-11. doi: $10.1080 / 13548506.2020 .1728350$.

18. Seguier J, Jouve E, Bobot M, Whalen E, Dussol B, Gentile S, Burtey S, Halfon P, Retornaz F, Chaussabel D, Chiche L, Jourde-Chiche N.
Paradoxical association between blood modular interferon signatures and quality of life in patients with systemic lupus erythematosus. Rheumatology (Oxford). 2019; Nov, 27. pii: kez541. doi: 10.1093/rheumatology/kez541.

19. Richter J, Fischer-Betz R, Winkler-Rohlfing B, Brinks R, Schneider M, Chehab G. Quality of care predicts outcome in systemic lupus erythematosus: a cross-sectional analysis of a German long-term study (LuLa cohort) Lupus 2020; 29:136-143.

20. Schiffenbauer J., Simon L.S. Randomized controlled trials in systemic lupus erythematosus: what has been done and what do we need to do? Lupus 2004; 13:398-405.

21. Strand V, Gladman D, Isenberg D, et al. Endpoints: consensus recommendations from OMERACT IV. Outcome Measures in Rheumatology. Lupus. 2000; 9(5):322-7.

DOI:http://dx.doi.org/10.1191/096120300678828424.

22. The World Health Organization Quality of Life assessment (WHOQOL): position paper from the World Health Organization. Soc Sci Med. 1995; 41:1403-1409.

23. Van Vollenhoven R, Mosca M, Bertsias G, et al. Treat-to-target in systemic lupus erythematosus: recommendations from an international task force. Ann Rheum Dis. 201; Jun, 4, 73(6):958-67. DOI: 10.1136/annrheumdis-2013-205139].

УДК $616-002.525: 615.825$

\section{МЕТОДЫ ОЦЕНКИ КАЧЕСТВА ЖИЗНИ БОЛЬНЫХ НА СИСТЕМНУЮ КРАСНУЮ ВОЛЧАНКУ}

М.А. Мазепа, И.В. Гавалко

Львовский государственный университет физической культуры имени Ивана Боберского, кафедра физической терапии и эрготерапии,

ORCID ID: 0000-0002-2199-4791,

ORCID ID: 0000-0003-4854-8043,

e-mail:mrmazepa@ukr.net

Резюме. В публикации представлены современные подходы к оценке качества (КЖ) жизни больных системной красной волчанкой (СКВ) и критический анализ методов оценки активности заболевания, общих и специфических опросников, которые наиболее объективно отражают состояние больного. Представленная публикация является нарративным обзором. Поиск данных проводили в базе статей в области медицины и биологии сайта PubMed Национального центра биотехнологической информации США (NCBI) и поисковой системе Google Scholar. Анализ литературы показал, что СКВ существенно ухудшает КЖ пациентов. У больных определена основная ключевая триада проблем, вызывающих ухудшение КЖ - усталость, боль и депрессия. Полезность общих опросников по КЖ у пациентов с СКВ определена не до конца, однако большинство авторов в качестве «золотого стандарта» рекомендуют использовать общий 
опросник - SF-36 (валидизированный в Украине). Из 60-ти индексов активности СКВ только пять прошли валидизацию и широко используются в мировой медицинской лечебной и научной практике. Приведенные специальные для СКВ опросники КЖ достаточно чувствительны к данной нозологии, они занимают немного времени для ответов. Их использование зависит от запроса пациента и целей, которые он ставит перед собой (Т2T). Опросник будет эффективным, если его правильно применить в каждом конкретном случае. Знание изменений результатов, сообщенных пациентом, против клинически значимых изменений в течении СКВ, имеет решающее значение для управления болезнью, направленного на персонализированную медицину. Важно, чтобы опросник был валидизован и приспособлен к условиям определенной страны. Специальные опросники КЖ больных СКВ нужно валидизировать Украине.

Ключевые слова: системная красная волчанка, активность, качество жизни, опросники.

UDC 616 - 002.525:615.825

METHODS OF ASSESSMENT OF THE QUALITY OF LIFE OF PATIENTS WITH SYSTEMIC LUPUS ERYTHEMATOSUS

\section{M.A. Mazepa, I.V. Havalko}

Lviv State University of Physical Culture of Ivan

Bobersky, Department of Rhysical therapy and

Occupation therapy,

ORCID ID: 0000-0002-2199-4791,

ORCID ID: 0000-0003-4854-8043,

e-mail:mrmazepa@ukr.net

Abstract. Systemic lupus erythematosus (SLE) is one of the most serious human autoimmune diseases, affecting almost all organs and systems. The quality of life of patients with SLE remains lower than the population level. Thanks to the assessment of quality of life, the patient can be assessed holistically, taking into account emotional and mental well-being, as well as socioeconomic factors. Assessing the QOL of a patient with SLE facilitates the planning of patient care and ensuring an appropriate relationship between physician, physical therapist, occupational therapist, and patient.
The publication presents modern approaches to assessing the quality of life (QL) of patients with systemic lupus erythematosus (SLE) and critical analysis of methods for assessing disease activity, general and specific questionnaires that most objectively reflect the patient's condition. The presented publication is a narrative review. The data were searched in a database of articles in the field of medicine and biology at the PubMed National Center for Biotechnology Information (NCBI) and the Google Scholar Search Engine. The analysis of the literature showed that SLE significantly worsens patients' QL. The main key triad of problems that cause worsening of QL has been identified in SLE patients - fatigue, pain, and depression. The usefulness of common QL questionnaires in patients with SLE are not fully studied, but most authors recommend the use of a common questionnaire SF-36 (validated in Ukraine) as a "gold standard". Among 60 activity indexes of SLE, only five have been validated and are widely used in the world of medical treatment and scientific practice - SLE Disease Activity Index (SLEDAI); Systemic Lupus Activity Measure (SLAM); European Consensus Lupus Activity Measurement (ECLAM); Lupus Activity Index (LAI); Classic British Isles Lupus Assessment Group Index (Classic BILAG Index). These special for SLE QL questionnaires are sufficiently sensitive to this nosology, and take a short time to respond. Their use depends on the patient's request and the goals he or she sets (T2T - treat to target). In these cases, it would be advisable to use LupusPRO. In $\boldsymbol{S L E - Q o L}$ more attention is paid to physical functioning, treatment, mood, self-image, in $\boldsymbol{L}-\mathbf{Q o L}$ - to self-care, fatigue, emotional reactions, in Lupus $Q o L$ - physical health, pain, intimate relationships, emotional health, body image, fatigue. Some questionnaires are used at low and medium activity index - LUP-QoL, others - at high. And in a questionnaire like LupusPRO, does not mention of the SELENA-SLEDAI index and the SLICC / ACR VP.

The questionnaire will be effective if applied rationally in each case. Awareness of the change in results, reported by the patient, about clinically relevant changes in the course of SLE, is critical to managing a personalized illness. It is important that the questionnaire is validated and adapted to the specific country. Special QL questionnaires for SLE patients need to be validated in Ukraine.

Keywords: systemic lupus erythematosus (SLE), activity, quality of life (QL), questionnaires. 